\title{
The Effects of Metal Ions on the DNA Damage Induced by Hydrogen Peroxide
}

\author{
So Kobayashi, Kazumitsu Ueda and Tohru Komano* \\ Laboratory of Biochemistry, Department of Agricultural Chemistry, \\ Kyoto University, Kyoto 606, Japan
}

Received June 12, 1989

\begin{abstract}
The effects of metal ions on DNA damage induced by hydrogen peroxide were investigated using two methods, agarose-gel electrophoretic analysis of supercoiled DNA and sequencing-gel analysis of single end-labeled DNA fragments of defined sequences. Hydrogen peroxide induced DNA damage when iron or copper ion was present. At least two classes of DNA damage were induced, one being direct DNA-strand cleavage, and the other being base modification labile to hot piperidine. The investigation of the damaged sites and the inhibitory effects of radical scavengers revealed that hydroxyl radical was the species which attacked DNA in the reaction of $\mathrm{H}_{2} \mathrm{O}_{2} / \mathrm{Fe}$ (II). On the other hand, two types of DNA damage were induced by $\mathrm{H}_{2} \mathrm{O}_{2} / \mathrm{Cu}(\mathrm{II})$. Type I damage was predominant and inhibited by potassium iodide, but type II was not. The sites of the base-modification induced by type I damage were similar to those by lipid peroxidation products and by ascorbate in the presence of $\mathrm{Cu}$ (II), suggesting the involvement of radical species other than free hydroxyl radical in the damaging reactions.
\end{abstract}

Various active oxygen species such as singlet oxygen, superoxide anion, hydrogen peroxide, and hydroxyl radicals are generated as byproducts during aerobic metabolisms in somatic cells. These highly reactive species have a wide potential for causing cell injury and even death. ${ }^{1)}$ Nucleic acids, enzymes, and membranes are all at risk of suffering the attack by free radicals. Especially, DNA seems important as a critical target because of its central role in genetic information. Damage in DNA induces mutations, which may be significant factors in aging, tumorigenesis, and heart disease. ${ }^{2,3)}$

Hydrogen peroxide $\left(\mathrm{H}_{2} \mathrm{O}_{2}\right)$ is one of the active oxygen species, capable of injuring DNA. ${ }^{4,5,6)}$ Although hydrogen peroxide is a relatively stable oxidant, it also produces various reactive chemicals in the presence of transition metal ions. The toxicity of hydrogen peroxide is thought to be mediated in part by a Fenton reaction. ${ }^{7)}$ The monovalent reduction of hydrogen peroxide can generate a hydroxyl radical $\left(\mathrm{HO}^{\circ}\right)$, which is one of the most harmful species. The hydroxyl radical is thought to attack both the deoxyribose sugars arrayed along the surface of $\mathrm{DNA}^{4,8)}$ and the bases of which is constructed the DNA molecule. ${ }^{6)}$ The resulting disintegration of the sugars themselves $^{9)}$ or alkali treatment of damaged DNA ${ }^{6}$ eventually induces single-strand cleavages in DNA.

Although the hydroxyl radical is an extremely reactive species and causes lethal damage in DNA, it is hard to imagine that free hydroxyl radicals, generated in cytoplasm as a by-product of oxidation-reduction reactions during metabolism, actually react with DNA in nuclei, since their diffusion distance is very short. We have investigated the DNA damage induced by lipid peroxidation products $^{10}$ and ascorbate ${ }^{11)}$ in the presence of $\mathrm{Cu}$ (II), and found that these damages were caused by oxygen free radicals generated from hydroperoxides. Hydroperoxides are accumulated during oxidation reactions of cel-

* To whom correspondence should be addressed. 
lular components such as lipids in membranes. These hydroperoxides generated and accumulated in cytoplasm could reach DNA in nuclei through chain reactions with cellular components. Since hydrogen peroxide could behave as a hydroperoxide derivative, it is interesting to investigate DNA damage induced by hydrogen peroxide in the presence of $\mathrm{Cu}(\mathrm{II})$.

In this paper, we compared the DNA damage induced by hydrogen peroxide in the presence of $\mathrm{Fe}(\mathrm{II})$ and those in the presence of $\mathrm{Cu}(\mathrm{II})$. The preferential damaged sites in DNA and the inhibitory effects of radical scavengers suggest that different radical species might be involved in the DNA-damaging reaction of $\mathrm{H}_{2} \mathrm{O}_{2} / \mathrm{Fe}(\mathrm{II})$ and in that of $\mathrm{H}_{2} \mathrm{O}_{2} / \mathrm{Cu}$ (II). Moreover, $\mathrm{H}_{2} \mathrm{O}_{2} / \mathrm{Cu}$ (II) induced two kinds of DNA damage, one similar to the DNA damage induced by lipid peroxidation products and ascorbate in the presence of $\mathrm{Cu}(\mathrm{II})$, and the other not.

\section{Materials and Methods}

Materials. Restriction enzymes HaeIII and ThH HB8I ( $\operatorname{Taq} \mathrm{I})$, and the Klenow fragment of DNA polymerase I of $E$. coli were obtained from Takara Shuzo Co. Catalase was purchased from Sigma Chemical Co. $\left[\alpha^{32} \mathrm{P}\right] \mathrm{dCTP}$ was from Amersham. Hydrogen peroxide and other chemicals were from Nacalai Tesque, Inc., and used without further purification. Bacteriophage $\phi \times 174$ double-stranded supercoiled DNA, which is a replicative form, was prepared as described previously. ${ }^{12)}$ Singly end-labeled DNA fragments of defined sequences were obtained from $\phi \times 174$ replicative form DNA as described previously. ${ }^{13}$

Reaction conditions for DNA damage. Reactions using $\phi \mathrm{X} 174$ double-stranded supercoiled DNA as a substrate for cleavage by hydrogen peroxide were done in $20 \mu \mathrm{l}$ of $10 \mathrm{~mm}$ Tris- $\mathrm{HCl}$ buffer ( $\mathrm{pH} 7.5$ ) and $50 \mu \mathrm{M}$ metal reagent. The concentration of DNA was $0.2 \mathrm{~mm}$ in DNA base pairs. Concentrations of hydrogen peroxide and other additions are noted in figure legends. The reaction was started by adding the metal reagent to the desired concentration as the last component, and the mixture was kept at $37^{\circ} \mathrm{C}$. The reaction was stopped by adding $5 \mu \mathrm{l}$ of $0.1 \mathrm{M}$ EDTA solution containing $50 \%(\mathrm{w} / \mathrm{v})$ sucrose and $0.1 \%$ bromophenol blue. The sample in a final volume of $25 \mu \mathrm{l}$ was analyzed by agarose gel electrophoresis $(1.2 \%$ agarose; running buffer, $40 \mathrm{~mm}$ Tris $-\mathrm{HCl} / 5 \mathrm{~mm}$ sodium acetate/1 mM EDTA (pH 7.1)).
To locate the sites of DNA damage, singly end-labeled DNA fragments (178 bp and $257 \mathrm{bp}$ long) from $\phi \times 174$ double-stranded replicative form DNA $(0.3-0.4 \mathrm{~mm}$ in DNA bp) were incubated with hydrogen peroxide as described in the figure legends. The reaction was started by adding the metal reagent as the last component, and stopped by the addition of EDTA (in a final concentration of $20 \mathrm{~mm}$ ) and $2 \mu \mathrm{g}$ of tRNA. The DNA was recovered by ethanol precipitation and purified by another ethanol precipitation. The recovered DNA was resuspended in $50 \mu \mathrm{l}$ of $1 \mathrm{M}$ piperidine; the suspension was heated at $90^{\circ} \mathrm{C}$ for $30 \mathrm{~min}$. The hot-piperidine treated DNA was then dried as in the procedure of Maxam and Gilbert, ${ }^{14)}$ and dissolved in $4 \mu \mathrm{l}$ of loading buffer containing $80 \%(\mathrm{v} / \mathrm{v})$ formamide, $10 \mathrm{~mm} \mathrm{NaOH}, 1 \mathrm{mM}$ EDTA, $0.1 \%$ bromophenol blue, and $0.1 \%$ xylene cyanol. The DNA was heated at $90^{\circ} \mathrm{C}$ for $1 \mathrm{~min}$ and put on a $8 \%$ polyacrylamide $8 \mathrm{M}$ urea slab gel for sequence analysis. The autoradiogram was scanned with a microdensitometer (Joyce Loebl and Co., Ltd. MK III CS double-beam recording microdensitometer). Sites of the DNA damage were located by direct comparison of the products with the oligonucleotides produced by the chemical reactions of the procedure of Maxam and Gilbert. ${ }^{14)}$

Measurement of DNA cleavage. When supercoiled DNA was used as a substrate, the mean number of single-strand cleavages per DNA molecule $(S)$ was calculated from the Poisson distribution: $S=-\ln f_{\mathrm{l}}$, where $f_{\mathrm{I}}$ is the fraction of form I (supercoiled) DNA molecules. When the cleavage reaction proceeded to produce form III (linear) DNA molecules, $S$ was calculated: $f_{\mathrm{I}}+f_{\mathrm{Il}}=[1-S(2 h+1) /(2 L)]^{S / 2}$, where $f_{\mathrm{II}}$ is the fraction of form II (open circular) molecules, $h$ is the distance between nicks on opposite strands needed to produce a linear molecule $(16 \mathrm{bp}),{ }^{4,15)}$ and $L$ is the total number of DNA bp in the $\phi \times 174$ replicativeform DNA (5386). ${ }^{16}$ The relative amounts of forms I, II, and III molecules were measured by scanning the photographic negatives of the agarose gel with a chromatoscanner (Shimadzu CS-900 dualwavelength TLC scanner).

\section{Results}

\section{Effects of added metal ions on DNA cleavage by hydrogen peroxide}

We examined the effects of added metal ions on the DNA cleavage reaction of hydrogen peroxide using supercoiled DNA as a substrate. Hydrogen peroxide induced DNA cleavage when $\mathrm{Fe}$ (II) or $\mathrm{Cu}$ (II) was added to the reaction mixture, although it did not induce DNA cleavage without any exogenous metal ions (Fig. 1). DNA cleavage by hydrogen peroxide in the presence of $\mathrm{Fe}(\mathrm{II})$ or in that of 


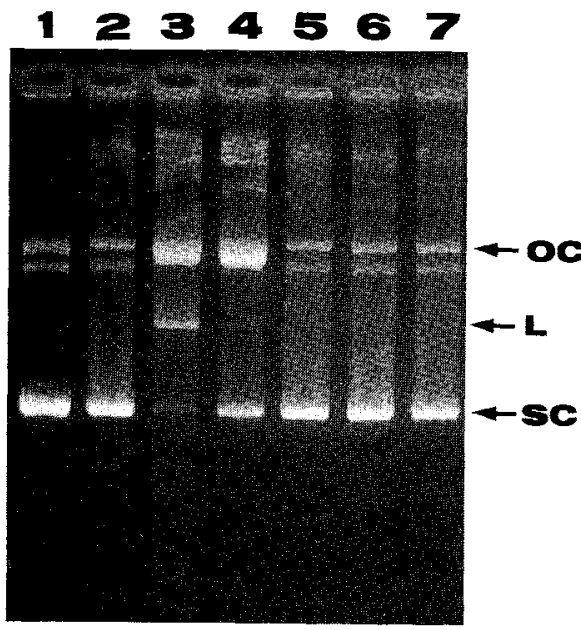

Fig. 1. Agarose Gel Electrophoretic Analysis of the Effects of Added Metal Ions on DNA Cleavage by Hydrogen Peroxide.

$\phi \mathrm{X} 174$ supercoiled DNA $(0.3 \mu \mathrm{g})$ was incubated with $0.1 \mathrm{~mm}$ hydrogen peroxide in the presence of $50 \mu \mathrm{M} \mathrm{FeSO}_{4}$ (lane 3), $\mathrm{CuCl}_{2}$ (lane 4), $\left[\mathrm{Co}\left(\mathrm{NH}_{3}\right)_{6}\right] \mathrm{Cl}_{3}$ (lane 5), $\mathrm{NiSO}_{4}\left(\mathrm{NH}_{4}\right)_{2} \mathrm{SO}_{4}$ (lane 6), or $\mathrm{ZnCl}_{2}$ (lane 7) in $10 \mathrm{~mm}$ Tris- $\mathrm{HCl}$ buffer $(\mathrm{pH} 7.5)$ at $37^{\circ} \mathrm{C}$ for $10 \mathrm{~min}$. Lanes 1 and 2 contain DNA incubated without and with hydrogen peroxide, respectively in the absence of metal ions. SC, supercoiled DNA; OC, open circular DNA; L, linear DNA.

$\mathrm{Cu}(\mathrm{II})$ was single-strand cleavage because of the appearance of open circular DNA, which was the product of single-strand cleavage of supercoiled DNA. The production of linear form DNA by $\mathrm{H}_{2} \mathrm{O}_{2} / \mathrm{Fe}$ (II) was the result of the accumulation of single-strand cleavages, because open circular DNA was predominantly produced in the early stage (data not shown).

The activities of DNA cleavage were estimated from the mean numbers of single-strand cleavages per DNA molecule $(S)$, which were calculated from the fractions of forms I and II DNA as described in Materials and Methods (Table I). The DNA-cleavage activity of $\mathrm{H}_{2} \mathrm{O}_{2} / \mathrm{Fe}$ (II) was five times higher than that of $\mathrm{H}_{2} \mathrm{O}_{2} / \mathrm{Cu}(\mathrm{II})$. No significant DNA cleavage was observed upon the addition of $\mathrm{Co}(\mathrm{II})$, $\mathrm{Ni}(\mathrm{II})$, or $\mathrm{Zn}(\mathrm{II})$. Exogenous metal chelating agents such as EDTA or DETAPAC at $10 \mathrm{~mm}$ inhibited DNA cleavage by hydrogen peroxide
Table I. EFfects of Added Metal Ions on DNA Cleavage Induced by Hydrogen Peroxide

\begin{tabular}{|c|c|c|c|c|}
\hline \multirow{2}{*}{ Added metal } & \multicolumn{3}{|c|}{ Form $(\%)^{a}$} & \multirow{2}{*}{$S^{b}$} \\
\hline & I & II & III & \\
\hline Drug-free control & 81 & 19 & 0 & 0.2 \\
\hline Metal-free control & 84 & 16 & 0 & 0.2 \\
\hline $\mathrm{Fe}(\mathrm{II})$ & 8 & 69 & 23 & 13 \\
\hline $\mathrm{Cu}$ (II) & 44 & 55 & 1 & 3 \\
\hline Co (II) & 89 & 11 & 0 & 0.1 \\
\hline $\mathrm{Ni}(\mathrm{II})$ & 85 & 15 & 0 & 0.2 \\
\hline $\mathrm{Zn}$ (II) & 84 & 16 & 0 & 0.2 \\
\hline
\end{tabular}

a The relative amounts of forms I, II, and III DNA molecules were measured by scanning the photographic negatives used in Fig. 1.

$b$ The mean numbers of single-strand cleavages per DNA molecule $(S)$ were calculated as described in Materials and Methods.

Table II. INHIBITORY EFFECTS OF RADICAL SCAVENGERS, Enzymes, and Metal Chelators on DNA Cleavage Hydrogen Peroxide AND METAL ION

\begin{tabular}{llcc}
\hline & & \multicolumn{2}{c}{ Inhibition $(\%)^{a}$} \\
\cline { 3 - 4 } \multicolumn{1}{c}{ Inhibitors } & Concn. & $+\mathrm{Fe}^{2+}$ & $+\mathrm{Cu}^{2+}$ \\
& & 10 & 88 \\
Potassium iodide & $50 \mathrm{~mm}$ & 17 & 0 \\
Sodium benzoate & $50 \mathrm{~mm}$ & 23 & 98 \\
Catalase & $10 \mu \mathrm{g} / \mathrm{ml}$ & $-{ }^{c}$ & 98 \\
SOD $^{c}$ & $50 \mu \mathrm{g} / \mathrm{ml}$ & 87 & 98 \\
EDTA $_{\text {DETAPAC }}^{b}$ & $10 \mathrm{~mm}$ & 85 & 98 \\
\hline
\end{tabular}

a $\phi$ X174 supercoiled DNA $(0.3 \mu \mathrm{g})$ was incubated with $0.1 \mathrm{~mm}$ hydrogen peroxide and inhibitor in the presence of $50 \mu \mathrm{M} \mathrm{FeSO}$ or $50 \mu \mathrm{M} \mathrm{CuCl}_{2}$ in $10 \mathrm{~mm}$ Tris- $\mathrm{HCl}$ buffer $(\mathrm{pH} 7.5)$ at $37^{\circ} \mathrm{C}$ for $10 \mathrm{~min}$. The mean numbers of single-strand cleavages per DNA molecule $(S)$ were calculated as described in Materials and Methods. Inhibition (\%) was calculated as $\left[\left(S_{0}-S\right) / S_{0}\right] \times 100$, where $S_{0}$ is the mean number of single-strand cleavages in the reaction without inhibitors. $S_{0}=21\left(\mathrm{Fe}^{2+}\right)$ and $11\left(\mathrm{Cu}^{2+}\right)$.

${ }^{b}$. SOD, superoxide dismutase; DETAPAC, diethylenediaminepentaacetic acid.

c SOD stimulated the DNA cleavage reaction of $\mathrm{H}_{2} \mathrm{O}_{2} / \mathrm{Fe}(\mathrm{II})$ and $\mathrm{H}_{2} \mathrm{O}_{2} / \mathrm{Cu}(\mathrm{II})$.

in the presence of $\mathrm{Fe}(\mathrm{II})$ or $\mathrm{Cu}(\mathrm{II})$ ions (Table II).

These results suggest that free metal ions, especially $\mathrm{Fe}(\mathrm{II})$ and $\mathrm{Cu}(\mathrm{II})$, are indispensable 
for DNA cleavage by hydrogen peroxide and that $\mathrm{Fe}(\mathrm{II})$ is more effective than $\mathrm{Cu}(\mathrm{II})$. We have reported that the DNA-cleavage activities of lipid peroxidation products ${ }^{10}$ and ascorbate $^{11)}$ were stimulated more effectively by the addition of $\mathrm{Cu}$ (II) than Fe(II). And it was suggested that radicals other than the hydroxyl radical were involved in the DNA damaging reactions caused by lipid peroxidation products and ascorbate in the presence of $\mathrm{Cu}(\mathrm{II})$. Hydrogen peroxide is thought to produce hydroxyl radicals, which damage DNA, in the presence of Fe(II) via the Fenton reaction, ${ }^{17)}$ but DNA damage by hydrogen peroxide in the presence of $\mathrm{Cu}(\mathrm{II})$ has not been well studied.

Sites of DNA damage induced by $\mathrm{H}_{2} \mathrm{O}_{2} / \mathrm{Fe}(\mathrm{II})$ or $\mathrm{H}_{2} \mathrm{O}_{2} \mathrm{Cu}(\mathrm{II})$

Sites of DNA damage induced by $\mathrm{H}_{2} \mathrm{O}_{2} /$ $\mathrm{Fe}(\mathrm{II})$ or $\mathrm{H}_{2} \mathrm{O}_{2} / \mathrm{Cu}$ (II) were investigated using a sequencing technique (Fig. 2). It is helpful to study the sites of DNA damage for recognizing the mechanisms of DNA-damaging reactions. $\mathrm{H}_{2} \mathrm{O}_{2} / \mathrm{Fe}(\mathrm{II})$ and $\mathrm{H}_{2} \mathrm{O}_{2} / \mathrm{Cu}(\mathrm{II})$ induced directstrand cleavage in DNA at any nucleotide (lanes 1 and 2). $\mathrm{H}_{2} \mathrm{O}_{2} / \mathrm{Cu}(\mathrm{II})$ produced very light bands under these conditions (lane 1), but by longer incubation it also produced a clear band ladder as $\mathrm{H}_{2} \mathrm{O}_{2} / \mathrm{Fe}(\mathrm{II})$ did (data not shown).

We have reported that lipid peroxidation products $^{10)}$ and ascorbate ${ }^{11)}$ in the presence of $\mathrm{Cu}$ (II) induced base modification labile to hot-piperidine treatment. Hydrogen peroxide was also supposed to induced base modifications in DNA other than the direct cleavage of the DNA backbone. To examine this possibility, DNA was treated with hot piperidine (1 $\mathrm{M}$ piperidine, $90^{\circ} \mathrm{C}$ for $30 \mathrm{~min}$ ) after the DNA-damaging reaction. The sequencing-gel electrophoretic analysis revealed that $\mathrm{H}_{2} \mathrm{O}_{2}$ / $\mathrm{Cu}(\mathrm{II})$ induced DNA damage labile to hot piperidine at specific sites (Fig. 2 lanes 4-6). The strength of the damage was dependent on the concentration of hydrogen peroxide. To locate the sites of DNA damage precisely, we scanned the autoradiogram in Fig. 2 with a

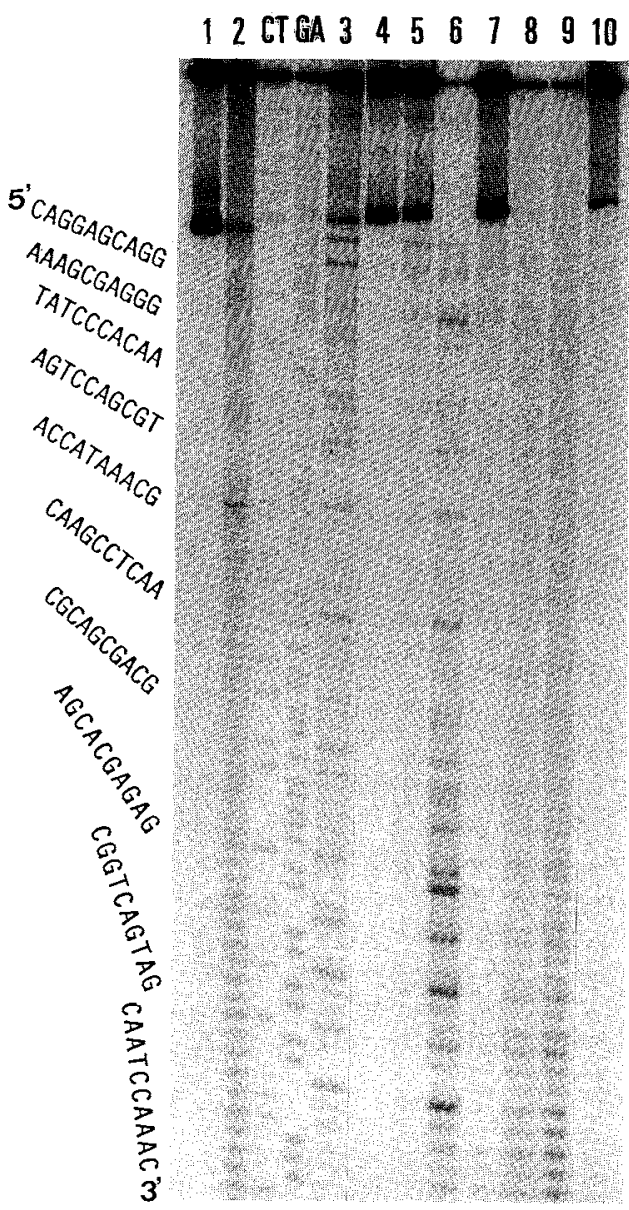

Fig. 2. Sequencing-gel Electrophoretic Analysis of Damaged Sites in DNA Induced by Hydrogen Peroxide.

The $3^{\prime}$-end-labeled DNA fragment 178 bp long $(0.3 \mathrm{~mm}$ bp) was incubated with hydrogen peroxide in $10 \mathrm{~mm}$ Tris $\mathrm{HCl}$ buffer ( $\mathrm{pH} \mathrm{7.5)}$ in the presence of $50 \mu \mathrm{M} \mathrm{CuCl}_{2}$ at $37^{\circ} \mathrm{C}$ for $30 \mathrm{~min}$ (lanes $1,4,5$, and 6) or in the presence of $50 \mu \mathrm{M}$ $\mathrm{FeSO}_{4}$ at $37^{\circ} \mathrm{C}$ for $10 \mathrm{~min}$ (lanes $2,7,8$, and 9). Concentrations of hydrogen peroxide were $10 \mu \mathrm{M}$ (lanes 4 and 7), $0.1 \mathrm{~mm}$ (lanes 1, 2, 5, and 8) and $1 \mathrm{~mm}$ (lanes 6 and 9). Lane 3 contains DNA incubated with $20 \mu \mathrm{M}$ ascorbate and $50 \mu \mathrm{M} \mathrm{CuCl}_{2}$ at $37^{\circ} \mathrm{C}$ for $120 \mathrm{~min}$, and lane 10 contains control DNA fragments. DNAs in lanes 3-10 were treated with hot piperidine as described in Materials and Methods. Lanes CT and GA are the products of base-specific chemical reactions. The sequence is indicated on the left of the figure.

microdensitometer. The relative positions of DNA damage labile to hot piperidine were found (Fig. 3) as described in Materials and Methods. $\mathrm{H}_{2} \mathrm{O}_{2} / \mathrm{Cu}$ (II) caused DNA damage labile to hot piperidine preferentially at pyrim- 
A
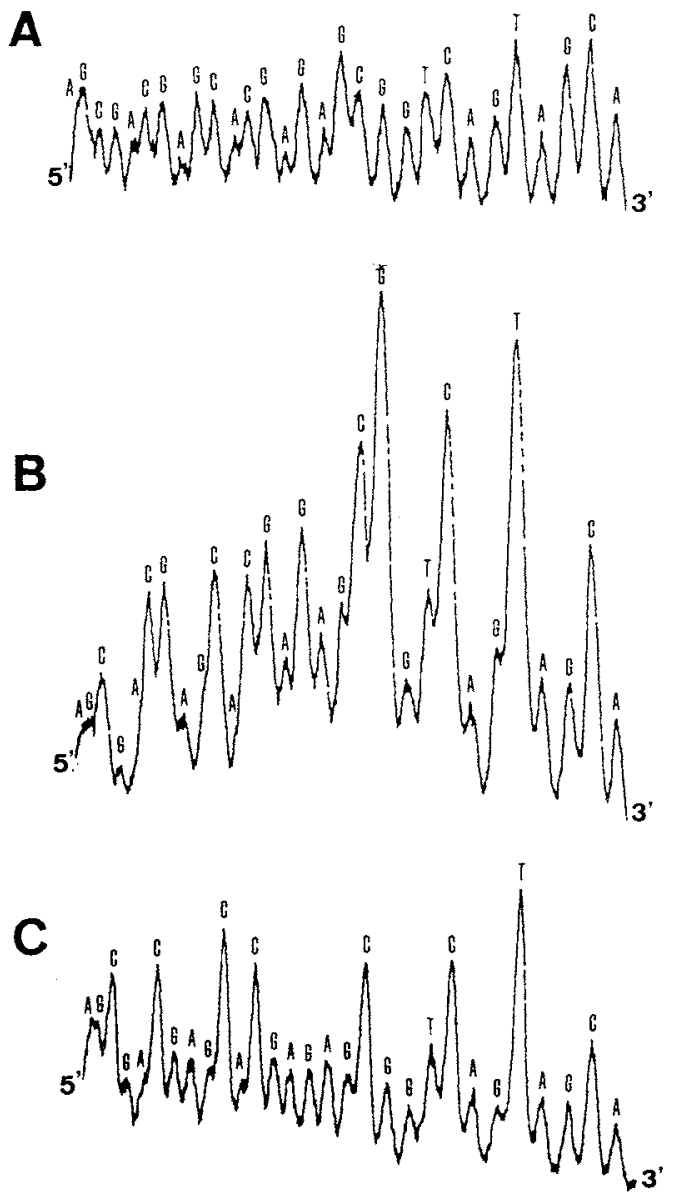

Fig. 3. Sites of Damage Labile to Hot Piperidine Induced by Hydrogen Peroxide in the Presence of $\mathrm{FeSO}_{4}$ or $\mathrm{CuCl}_{2}$.

The autoradiogram in Fig. 2 was scanned with a microdensitometer, and the sites of damage labile to hotpiperidine treatment after the reaction with hydrogen peroxide and metal ions were found as described in Materials and Methods. (A) Sites of DNA damage induced by $0.1 \mathrm{~mm}$ hydrogen peroxide and $50 \mu \mathrm{M} \mathrm{FeSO}_{4}$ (lane 8 in Fig. 2). (B) $1 \mathrm{~mm}$ hydrogen peroxide and $50 \mu \mathrm{M}$ $\mathrm{CuCl}_{2}$ (lane 6 in Fig. 2). (C) $20 \mu \mathrm{M}$ ascorbate and $50 \mu \mathrm{M}$ $\mathrm{CuCl}_{2}$ (lane 3 in Fig. 2).

idine residues and guanine residues at the $5^{\prime}$ side of purine residues (Fig. 3B). Interestingly, the sites of the preferentially damaged pyrimidine residues were identical to the sites damaged by ascorbate and $\mathrm{Cu}$ (II) (Fig. 2 lane 3 and Fig. 3C).

$\mathrm{H}_{2} \mathrm{O}_{2} / \mathrm{Fe}$ (II) also induced DNA damage labile to hot piperidine in proportion to the concentration of hydrogen peroxide (Fig. 2 lanes 7-9). DNA damage induced by $\mathrm{H}_{2} \mathrm{O}_{2} / \mathrm{Fe}(\mathrm{II})$ occurred almost randomly at any nucleotides except adenine residues. The preferential sites of the damage induced by $\mathrm{H}_{2} \mathrm{O}_{2} / \mathrm{Fe}(\mathrm{II})$ were clearly different from those induced by $\mathrm{H}_{2} \mathrm{O}_{2} / \mathrm{Cu}(\mathrm{II})$. These results suggest that different radical species might be generated from $\mathrm{H}_{2} \mathrm{O}_{2} / \mathrm{Fe}(\mathrm{II})$ and $\mathrm{H}_{2} \mathrm{O}_{2} / \mathrm{Cu}(\mathrm{II})$ and induced different kinds of DNA damage.

\section{Involvement of radical species in DNA-cleavage reaction of $\mathrm{H}_{2} \mathrm{O}_{2} / \mathrm{Fe}(\mathrm{II})$ and $\mathrm{H}_{2} \mathrm{O}_{2} / \mathrm{Cu}(I I)$}

The difference of the preferentially damaged sites induced by $\mathrm{H}_{2} \mathrm{O}_{2} / \mathrm{Fe}(\mathrm{II})$ and $\mathrm{H}_{2} \mathrm{O}_{2} / \mathrm{Cu}(\mathrm{II})$ could be due to a difference of radical species involved in the DNA-damaging reactions. To identify the radical species involved, we examined the inhibitory effects of radical scavengers and enzymes on DNA cleavage of supercoiled DNA (Table II). Catalase, which catalyzes the decomposition of hydrogen peroxide, inhibited both reactions, although the inhibitory effect against the reaction of $\mathrm{H}_{2} \mathrm{O}_{2} / \mathrm{Cu}(\mathrm{II})$ was much higher than against that of $\mathrm{H}_{2} \mathrm{O}_{2} / \mathrm{Fe}(\mathrm{II})$. The DNA cleavage reaction of $\mathrm{H}_{2} \mathrm{O}_{2} / \mathrm{Fe}$ (II) with supercoiled DNA was finished within 10 sec, but that of $\mathrm{H}_{2} \mathrm{O}_{2} / \mathrm{Cu}(\mathrm{II})$ proceeded for longer than $30 \mathrm{~min}$ (data not shown). The reaction of hydrogen peroxide with $\mathrm{Fe}$ (II) is supposed to be so fast that the reaction proceeds before catalase reacts with hydrogen peroxide.

Potassium iodide and sodium benzoate showed distinct effects. Potassium iodide, which reacts with hydroperoxides to produce alcohol and $\mathrm{H}_{2} \mathrm{O}$, inhibited the DNA cleavage by $\mathrm{H}_{2} \mathrm{O}_{2} / \mathrm{Cu}(\mathrm{II})$ almost completely, but it had a very weak inhibitory effect on the DNA cleavage by $\mathrm{H}_{2} \mathrm{O}_{2} / \mathrm{Fe}(\mathrm{II})$. On the other hand, sodium benzoate, which is a scavenger of hydroxyl radicals, weakly inhibited the cleavage by $\mathrm{H}_{2} \mathrm{O}_{2} / \mathrm{Fe}(\mathrm{II})$, but not the cleavage by $\mathrm{H}_{2} \mathrm{O}_{2} / \mathrm{Cu}(\mathrm{II})$.

We were interested in the strong inhibitory effects of potassium iodide on the DNAcleavage reaction of $\mathrm{H}_{2} \mathrm{O}_{2} / \mathrm{Cu}(\mathrm{II})$. We further investigated the inhibitory effect of potassium 
iodide on the DNA-damaging reaction using end-labeled DNA fragments as a substrate (Fig. 4). Potassium iodide inhibited the DNAdamaging reaction of $\mathrm{H}_{2} \mathrm{O}_{2} / \mathrm{Cu}$ (II). The scanning patterns clearly show that potassium iodide inhibited the damage specially at pyrimidine and guanine residues at the $5^{\prime}$ side of purine residues. The base modification occurring at other guanine residues was not inhibited by potassium iodide. These results indicated that at least two types of DNA damage were induced by $\mathrm{H}_{2} \mathrm{O}_{2} / \mathrm{Cu}(\mathrm{II})$, one (type I) inhibited by potassium iodide and the other (type II) not inhibited. Because potassium iodide did not inhibit the DNA damage induced by $\mathrm{H}_{2} \mathrm{O}_{2} / \mathrm{Fe}$ (II) (Fig. 4B), the radical species involved in the type I DNA-damaging reaction of $\mathrm{H}_{2} \mathrm{O}_{2} / \mathrm{Cu}$ (II) was different from the radical species involved in the other reactions.

\section{Discussion}

We have investigated the DNA damage induced by hydrogen peroxide in the presence of $\mathrm{Fe}(\mathrm{II})$ or $\mathrm{Cu}$ (II) using two methods. One is the agarose-gel electrophoretic analysis of supercoiled DNA, and the other is the sequencing-gel electrophoretic analysis of endlabeled DNA fragments with defined sequences. These analyses revealed that hydrogen peroxide induced DNA damage only in combination with iron or copper ion, and at least two classes of DNA damage were induced, one being direct DNA-strand cleavage, and the other being base modification labile to hot piperidine. The direct DNA-strand cleavage induced by both $\mathrm{H}_{2} \mathrm{O}_{2} / \mathrm{Fe}$ (II) and $\mathrm{H}_{2} \mathrm{O}_{2}$ / $\mathrm{Cu}$ (II) occurred uniformly at any nucleotide.

The base modification labile to hot piperidine induced by $\mathrm{H}_{2} \mathrm{O}_{2} / \mathrm{Fe}(\mathrm{II})$ was observed almost randomly at any nucleotides except for
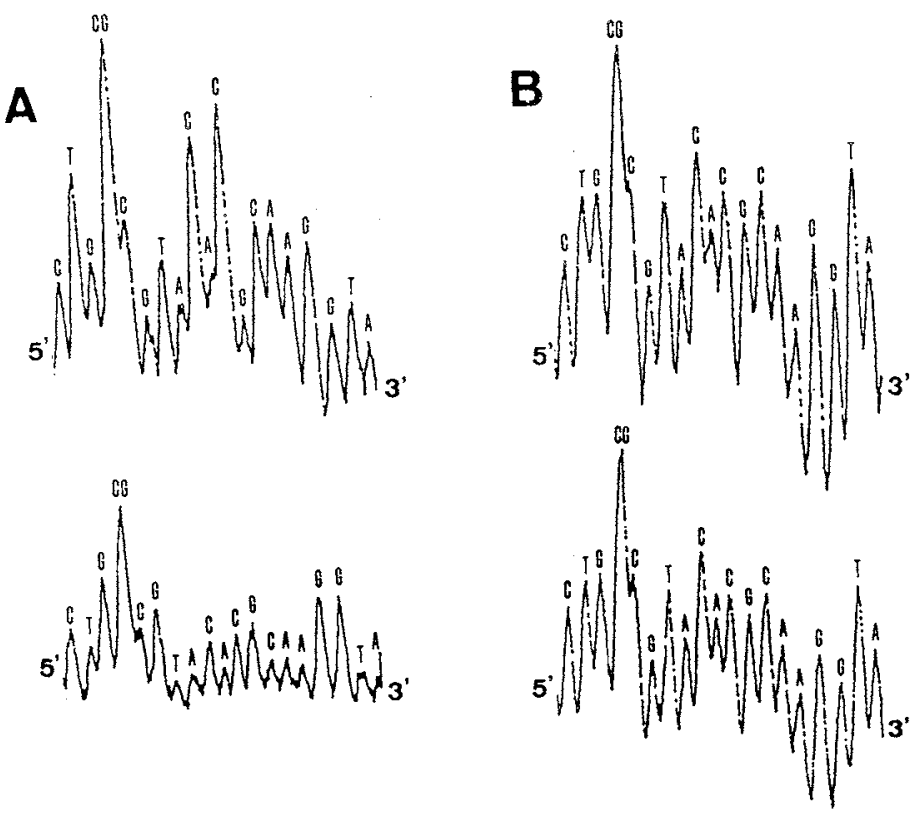

Fig. 4. Inhibition Pattern of Potassium Iodide on the DNA Damage Induced by Hydrogen Peroxide and $\mathrm{CuCl}_{2}$ or $\mathrm{FeSO}_{4}$

The 3 '-end-labeled DNA fragment $257 \mathrm{bp}$ long $(0.4 \mathrm{mM}$ bp) was incubated with $0.1 \mathrm{~mm}$ hydrogen peroxide in the presence of $50 \mu \mathrm{M} \mathrm{CuCl}$ (A) or $50 \mu \mathrm{M} \mathrm{FeSO}$ (B) without (upper panels) or with (lower panels) $50 \mathrm{~mm}$ potassium iodide at $37^{\circ} \mathrm{C}$ for $20 \mathrm{~min}$ (A) or $5 \mathrm{~min}(\mathrm{~B})$. After the reaction, the DNA fragment was treated with hot piperidine and put on a sequencing gel. The autoradiogram was scanned with a microdensitometer and the sites of DNA damages and the relative amounts of oligonucleotides produced were analyzed as in Materials and Methods. 
adenine residues, which may reflect the tendency in the reaction rate of mononucleotides with hydroxyl radicals $(\mathrm{dGMP}>\mathrm{dTMP}>$ $\mathrm{dCMP}>\mathrm{dAMP}){ }^{18)}$ On the other hand, the base modifications induced by $\mathrm{H}_{2} \mathrm{O}_{2} / \mathrm{Cu}$ (II) were sequence- or base-specific. More detailed investigation (Fig. 4) revealed that $\mathrm{H}_{2} \mathrm{O}_{2} /$ $\mathrm{Cu}(\mathrm{II})$ induced two types of base modification in DNA. Type I base-modification was sequence-specific, occurring at pyrimidine and guanine residues at the $5^{\prime}$ side of purine residues, and was inhibited by potassium iodide. Type II was base-specific at guanine residues, which was not inhibited by potassium iodide. Type I base-modification seems predominant because the cleavage of supercoiled DNA was inhibited almost completely by potassium iodide. The sequence-specificity of the DNA damage and the inhibitory effect of radical scavengers suggested that the molecule inducing the type I base-modification in the reaction of $\mathrm{H}_{2} \mathrm{O}_{2} / \mathrm{Cu}$ (II) is similar to that in the reactions of ascorbate ${ }^{11)}$ or lipid peroxidation products ${ }^{10}$ ) in the presence of $\mathrm{Cu}$ (II) and is different from that in the reaction of $\mathrm{H}_{2} \mathrm{O}_{2} / \mathrm{Fe}(\mathrm{II})$.

Hydrogen peroxide is postulated to be reduced in a Fenton type reaction and to produce hydroxyl radicals in the presence of $\mathrm{Fe}(\mathrm{II})$.

$$
\mathrm{H}_{2} \mathrm{O}_{2}+\mathrm{Fe}^{2+} \rightarrow \mathrm{Fe}^{3+}+\mathrm{OH}^{-}+\mathrm{HO}^{\cdot}
$$

The tendency in the damaged nucleotides $(\mathrm{G}>\mathrm{T}>\mathrm{C}>\mathrm{A})$ and the inhibition of the DNA cleavage by sodium benzoate, although it was weak, suggest that the hydroxyl radical is the species which attacks DNA in the damaging reaction of $\mathrm{H}_{2} \mathrm{O}_{2} / \mathrm{Fe}(\mathrm{II})$.

In the reaction of $\mathrm{H}_{2} \mathrm{O}_{2} / \mathrm{Cu}$ (II), the first reaction should be the reduction of $\mathrm{Cu}(\mathrm{II})$.

$$
\mathrm{Cu}^{2+}+\mathrm{H}_{2} \mathrm{O}_{2} \rightarrow \mathrm{Cu}^{+}+\mathrm{H}^{+}+\mathrm{HO}_{2} \cdot
$$

This reaction proceeds slowly. The production of $\mathrm{Cu}(\mathrm{I})$ could be confirmed by measuring the color-product of $\mathrm{Cu}(\mathrm{I})$-chelated bathocuproinedisulfonic acid (data not shown). The rate of the DNA cleavage by $\mathrm{H}_{2} \mathrm{O}_{2} / \mathrm{Cu}$ (II) is slow and is limited by this step. Copper is capable of serving in Fenton reactions.

$$
\begin{aligned}
& \mathrm{Cu}^{+}+\mathrm{H}_{2} \mathrm{O}_{2} \rightarrow \mathrm{Cu}^{2+}+\mathrm{HO}^{\circ}+\mathrm{OH} \\
& \mathrm{HO}^{\circ}+\mathrm{H}_{2} \mathrm{O}_{2} \rightarrow \mathrm{HO}_{2}^{*}+\mathrm{H}_{2} \mathrm{O} \\
& \mathrm{HO}_{2}^{\circ}+\mathrm{Cu}^{2+} \rightarrow \mathrm{O}_{2}+\mathrm{Cu}^{+}+\mathrm{H}^{+} \\
& 2 \mathrm{H}_{2} \mathrm{O}_{2} \rightarrow \mathrm{O}_{2}+2 \mathrm{H}_{2} \mathrm{O}
\end{aligned}
$$

Because the damaged sites were sequencespecific and because sodium benzoate had no effect on the DNA cleavage by $\mathrm{H}_{2} \mathrm{O}_{2} / \mathrm{Cu}(\mathrm{II})$, free hydroxyl radicals may not be responsible for the type I DNA damage, although the involvement of hydroxyl radicals is still possible in the type II guanine-specific DNA damage. We postulate the formation of the $\mathrm{Cu}^{+}-\mathrm{HO}_{2}{ }^{-}$complex or the $\mathrm{Cu}^{2+}-\mathrm{HO}^{*}$ complex and the direct involvement of these complexes in the DNA damage.

$$
\begin{aligned}
& \mathrm{Cu}^{2+}+\mathrm{H}_{2} \mathrm{O}_{2} \rightarrow \mathrm{Cu}^{+}-\mathrm{HO}_{2}^{+}+\mathrm{H}^{+} \\
& \mathrm{Cu}^{+}+\mathrm{H}_{2} \mathrm{O}_{2} \rightarrow \mathrm{Cu}^{2+}-\mathrm{HO}^{-}+\mathrm{OH}
\end{aligned}
$$

Hydrogen peroxide reacts with $\mathrm{Cu}(\mathrm{II})$ or $\mathrm{Cu}(\mathrm{I})$ complexed to the DNA, the $\mathrm{Cu}(\mathrm{I})$ - or $\mathrm{Cu}(\mathrm{II})$ complex of active oxygen bound to the specific sites of DNA sequence directly may react with DNA. Sodium benzoate may fail to react with these complexes. The DNA damage of this type is also induced by ascorbate and lipid peroxidation products and is, therefore, biologically important.

\section{References}

1) H. Sies, "Oxidative Stress," Academic Press, London, 1985.

2) D. Decuyper-Debergh, J. Piette and A. Van de Vorst, EMBO J., 6, 3155 (1987).

3) B. N. Ames, Science, 221, 1256 (1983).

4) R. P. Hertzberg and P. B. Dervan, Biochemistry, 23, 3934 (1984).

5) J. A. Imlay and S. Linn, Science, 240, 1302 (1988).

6) S. Inoue and S. Kawanishi, Cancer Res., 47, 6522 (1987).

7) H. J. H. Fenton, J. Chem. Soc., 65, 899 (1984)

8) T. D. Tullius and B. A. Dombroski, Proc. Natl. Acad. Sci. U.S.A., 83, 5469 (1986).

9) J. C. Wu, J. Kozarich and J. Stubbe, J. Biol. Chem., 258, 4694 (1983)

10) K. Ueda, S. Kobayashi, J. Morita and T. Komano, Biochim. Biophys. Acia, 824, 341 (1985). 
11) S. Kobayashi, K. Ueda, J. Morita, H. Sakai and T. Komano, Biochim. Biophys. Acta, 949, 143 (1988).

12) K. Ueda, J. Morita and T. Komano, J. Antibiot., 34, 317 (1981).

13) J. Morita, K. Ueda, S. Nanjo and T. Komano, Nucleic Acids Res., 13, 449 (1985).

14) A. M. Maxam and W. Gilbert, Methods Enzymol., 65, 499 (1980).

15) D. Freifelder and B. Trumbo, Biopolymers, 7, 681 (1969).
16) F. Sanger, A. R. Coulson, T. Friedmann, G. M. Air, B. G. Barrell, N. L. Broun, I. C. Fiddes, C. A. Hutchison, III, P. M. Slocombe and M. Smith, J. Mol. Biol., 125, 225 (1978).

17) W. A. Pryor, "Free Radicals," McGraw-Hill Inc., New York, 1966, pp. 135-145.

18) G. Scholes, in "Photochemistry and Photobiology of Nucleic Acids," Vol. 1, ed. by S. Y. Wang, Academic Press, New York, 1976, pp. 521-577. 